\title{
The role of traditional institutions in implementing the empowerment policy of Oetulu village, Musi district, Timor Tengah Utara regency
}

Yohanes K. Olin ${ }^{1 *}$, Petrus Kase ${ }^{2}$, Hendrik Toda ${ }^{3}$

Regional Personnel Agency, Timor Tengah Utara Regency, Indonesia ${ }^{1 *}$

Department of Administrative Sciences, Nusa Cendana University, Kupang, Indonesia ${ }^{2,3}$ jhonolin07@gmail.com ${ }^{1 *}$,kasepetrus@yahoo.co.id ${ }^{2}$,hendrik.toda2012@gmail.com ${ }^{3}$

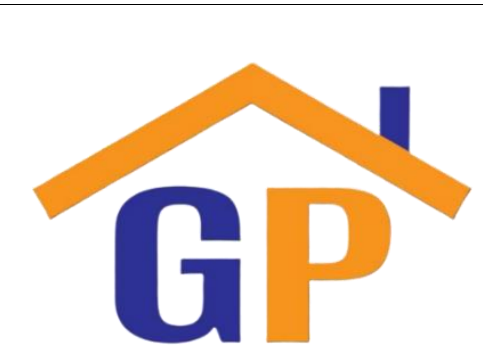

Article History

Received on 8 November 2020

Revised on 2 December 2020

Accepted on 3 December 2020

\begin{abstract}
Purpose: This study aimed to determine the role of indigenous institutions in implementing the Oetulu village Empowerment Policy of Musi district of Timor Tengah Utara regency.

Research methodology: The research method in this study was a descriptive research method with a qualitative approach. This study used policy implementation theory models from Donald Van Meter and Carl E. Van Horn (1975)).

Results: Six variables affect the implementation, namely: First, policy standards in the form of rules related to indigenous institutions in Oetulu village have been flawed at the formulation stage. Second, the human resources of Oetulu village indigenous institutions are not utilized by the Village Government. Third, communication between organizations and strengthening activities is still not effective. Fourth, the implementing agent has an open level of communication both vertically and horizontally, but this communication is constrained at the vertical level. Fifth, economic conditions in the jurisdiction or implementing organization are not enough to support the implementation of the policy and. Sixth, the disposition of the implementer.
\end{abstract}

Limitations: This research only discusses the role of indigenous institutions in implementing the community empowerment policy of Oetulu village, Musi district of Timor Tengah Utara regency.

Contribution: This research becomes scientific information for public administration science.

Keywords: Indigenous institutions, Communities, Implementation

How to cite: Olin, Y. K., Kase, P., \& Toda, H. (2021). The role of traditional institutions in implementing the empowerment policy of Oetulu village, Musi district, Timor Tengah Utara regency. Journal of Governance and Accountability Studies, 1(2), 145-161.

\section{Introduction}

Indonesia is made up of numerous tribes and customs that range from Sabang to Merauke. Frequently, diversity contains customs and traditions that are unique to a particular society. Thus, establishing a traditional institution in the village enables the administration to shape the community's customs more precisely. Indigenous peoples are dispersed throughout the Archipelago as a constituent of the Republic of Indonesia and reflect Indonesia's pluralism. Around 70 million Indigenous people live in 2,371 indigenous communities across the country's 31 provinces. From the diverse indigenous peoples scattered throughout Indonesia, a policy that can accommodate all indigenous activities is required. Law No. 6 of 2014 on Villages is one of the policies governing indigenous peoples.Indigenous peoples can establish an indigenous institution in their village to empower the 
community under this policy.

According to the explanation provided in Article 5 of the Republic of Indonesia's Law No. 6 of 2014 on villages, there are three types of village institutions: (a) Village Government Institutions, (b) Village Community Institutions, and (c) Village Indigenous Institutions. Each of these types of village institutions is a device of the organization that grows and develops in tandem with the history of an indigenous legal community. Oetulu village Musi district of Timor Tengah Utara regency is one of the villages in East Nusa Tenggara Province with a Customary Institution. In the Oetulu village Musi district of Timor Tengah Utara regency, the traditional institution is a vital component of customs administration, development, and village government implementation. In Oetulu village, traditional institutions have been instrumental in implementing government, particularly in the context of community empowerment.

Indigenous institutions in Oetulu village Musi district of Timor Tengah Utara regency strongly influence people's lives. They are respected and followed by the community, as evidenced by their ability to organize and exercise customs and address social problems in the indigenous community. Indigenous leaders and devices must recognize this and further maximize indigenous institutions' role. This is in accordance with the Minister of Home Affairs of the Republic of Indonesia's Regulation No. 18 of 2018 on Village Community Institutions and Village Customary Institutions, which states that the Village Indigenous Institution (LAD) is tasked with assisting the Village Government and working as a partner in empowering, preserving, and developing customs as a means of acknowledging the customs of the village.

The concept of empowerment emerged as a result of actions and reactions to the nature of the mind, the social system, and the previous cultural system that developed in a country; in essence, empowerment was placed on an individual and social level (Surjono, Nugroho, 2007:25). Empowerment has become a new mainstream concept in the effort to improve welfare and poverty alleviation in society. In this context, empowerment refers to what the community owns as a development resource that must be developed to maximize its utility to the community. Empowerment also occurs due to a process, a mechanism by which individuals, organizations, and communities interact. (Strzelecka et al., 2017).

Oetulu village has 12 community empowerment groups engaged in various business activities, including craftsmen, ikat weaving, savings and lending, and agricultural business. However, at the implementation level, indigenous village institutions engaged in community empowerment are frequently underutilized. Indigenous institutions are also not always incorporated into policy formulations in Oetulu village, Musi district, Timor Tengah Utara regency, nor have traditional administrators been able to increase the community's active role, particularly in developing and preserving cultural heritage values aimed at promoting community empowerment through indigenous institutions.

The following phenomena occur in Oetulu village, Musi district, Timor Tengah Utara regency, concerning the role of indigenous village institutions: (1). Indigenous institutions serve no purpose in health, education, social and economic empowerment, or community empowerment; (2). The customary institution lacks a draft program/activity that is consistent with village customs; (3). The governing body of a customary institution does not have a place of business/workspace dedicated to service/program/activity implementation; (4). Village government activities are typically carried out without the involvement of community institutions, preferring instead to involve citizens. This implies that communication between the village government and the forum of indigenous community institutions in the village is not optimal; (5). The Oetulu village Government does not appear to have given indigenous institutions a role in establishing an order based on indigenous values (6). Technological advancements are gradually eroding indigenous values.

The position of indigenous institutions formed by the community in the hope of fostering an understanding of the importance of building villages according to local values cannot be realized due 
to the character of the local community and tends to use indigenous institutions only as a formal institution that meets the village government's structure but plays no role in the planning process. This is an inconsistency in organizing the local village government, as the village government does not assign duties and functions for village government implementation.

With the aforementioned description, to analyze the role of indigenous institutions in implementing the community empowerment policy of Oetulu village Musi district of Timor Tengah Utara regency, the author used a theory from Van Meter and Van Horn (1975) called A Model of the Policy Implementation. These model preoccupations implement policies that run linearly from public policy, implementers, and public policy performance. This model is not essentially intended to measure and explain the final outcome of government policy, but rather to measure and explain the so-called achievement of the program because it thinks a policy may be implemented effectively, but fails to have a substantial impact as the policy is not well structured or due to other circumstances. In theory, Van Meter and Van Horn (1975) start from an assumption that the implementation process will vary according to the nature of the policy implemented. Furthermore, Van Meter and Van Horn offer characteristics in the implementation process; first, the implementation process will be influenced by how the policy deviates from the previous policies. Second, the implementation process will be affected by a number of organizational changes required.

Based on the formulation of the background above, researchers were interested in researching with the title "The Role of Indigenous Institutions in the Implementation of Oetulu village Empowerment Policy of Musi district of Timor Tengah Utara regency."

\section{Literature review}

\subsection{Role}

In this study, the authors formulated the study's title on the role of indigenous institutions in implementing the community empowerment policy of Oetulu village Musi district of Timor Tengah Utara regency. Based on the title of the study, the authors will discuss in more depth the theory of the role that the author will eventually use as a reference theory to see and analyze the extent of the role of indigenous institutions in the implementation of the policy of empowering the people of Oetulu village Musi district, Timor Tengah Utara regency. Understanding the role will be explained more deeply as follows: In general, the role is the behavior that a person does regarding his/her position in the social structure or social group in society, meaning that each person has his/her own role according to the position held. According to Soerjono Soekanto (2006:212), the role is a dynamic aspect of status when a person exercises rights and obligations according to his position. According to Abdulyani (2012:94) saying "a role is an act of a person in a certain way in the effort to exercise his rights and obligations in accordance with his/her status, and a person can be said to play a role if he has exercised his rights and obligations in accordance with his social status in society.

Based on the above understanding, it can be concluded that the role is a pattern of collective behavior that others expect against a person against as a form of status to exercise his rights and obligations in accordance with what other members of society expect. The role is a dynamic aspect of the position. If a person exercises his rights and his/her rights in his position, he performs a role. The importance of the role is because it regulates one's behavior. The role of causing a person to some extent is able to foresee the actions of others.

\subsection{Public policies}

State policies and policies are often referred to as public policy. State policy or government wisdom actually have the same meaning. Friedrich (1969) in Aritonang (2011) states that a policy is a series of actions proposed by a person, group, government, or a particular environment by showing the obstacles of opportunities for implementing such policy proposals to achieve particular objectives.

Another policy understanding put forward by Nugroho (2006:23) that makes the formula of public policy. First, public policy is a policy created by a state administrator or a public administrator. So, 
public policy is everything that the government does and does not do. Second, Public policy governs shared life or public life, not the life of a person or person. Public policy governs everything in the domain of a public administrator institution. Public policy governs shared or private, or group issues that are already a problem of the entire community in the area. Third, it is said to be public policy if the benefits gained by people who are not direct users of the resulting product are much greater than their direct users.

From some of these descriptions, it can be seen that public policy is a complex process. Nevertheless, without intending to reduce the complexity, the authors can conclude that public policy is a series of decision and action processes carried out by the government to solve problems arising in society.

\subsection{Policy implementation}

Implementation related to various activities is directed to the realization of the program. In this case, the administrator sets up a way to organize, interpret and implement the selected policies. Organizing means organizing resources, units, and methods to implement the program. The explanation quoted the opinion of Nugroho (2006:158), which stated that the implementation of the policy is a way for a policy to achieve its goals. To implement public policy, there are two options of measures that exist, namely directly implementing in the form of programs or through derivative or derivative policy formulations of such public policy. While according to Soenarko (2005:180), in implementing public policy, there are several provisions that must be met and done to succeed, the provision concerns the authority of the implementor, the content of the policy, the legitimacy of the people and so on.

To find out the extent of the role of indigenous institutions in the implementation of the community empowerment policy of Oetulu village Musi district of Timor Tengah Utara regency, this research uses the policy implementation model of Donald S. Van Meter and Carl E. Van Horn (1975) with the following explanations:

\section{Model Implementation Policy}

This policy implementation process is an abstraction or performance of a policy that is basically done to achieve high public policy implementation performance. This model feeds the linear implementation of policies from available political decisions, executors, and public policy performance. According to Van Meter and Van Horn (1975), there are six variables that affect the implementation of the policy, namely:

a. Policy standards and objectives

Policy standards and objectives must be clear and measurable so as not to give rise to interpretations that could lead to conflicts among implementation agencies. Policy standards and objectives are required to direct in implementing the policy. It is done to comply with the planned program. The standard role of indigenous institutions in the implementation of the Policy of Empowerment of The People of Oetulu district, Timor Tengah Utara regency is the Regulation of the Minister of Home Affairs of the Republic of Indonesia No. 18 of 2018 on Village Community Institutions and Village Indigenous Institutions stating that the Village Customary Institution (LAD) is tasked with assisting the Village Government and as a partner in empowering, preserving, and developing customs as a form of recognition to the customs of the villagers so that it is clearly known that one of the duties of the Village Indigenous Institution is to empower the community. At the same time, the target of this policy is the people of Oetulu village, Musi district, Timor Tengah Utara.

b. Resources

Policies need to be supported by resources, be they human resources or non-human resources. These policy resources are indispensable for the success of a policy made by the government. Human resources are very important because as a source of mobilization and implementing policies, capital is necessary for the smooth financing of policies so as not to impede the policy process. Time is an important part of policy implementation because time is a supporter of policy success. Time resources are the government's determinant in planning and implementing policies. 
c. Communication between organizations and strengthening activities

In many cases, the implementation of a program sometimes needs to be supported and coordinated with other agencies in order to achieve the desired success. This is very important because the performance of public policy implementation will be very much influenced by the right characteristics and suitable with the agencies or implementing agencies. The components of this model consist of the formal structures of the organizations and the unusual attributes of their personnel, in addition, attention also needs to be directed to the bonds of the implementing bodies with exhibitions and in the delivery of policies related to the role of indigenous institutions in the implementation of the community empowerment policy of Oetulu village Musi district of Timor Tengah Utara regency.

d. Characteristic managing agent

The extent to which the interest groups in this study are the traditional institutions of Oetulu village implemented the policy of empowering the people of Oetulu village Musi district Have Timor Tengah Utara regency as well as providing support for the implementation of the policy. This includes supporting or rejecting participants, as well as the nature of public opinion in the environment and whether the political elite supports policy implementation. The characteristics of the implementing agent are to include bureaucratic structures, norms, and patterns of relations that occur in the bureaucracy that implements community empowerment policies in Oetulu village Musi district of Timor Tengah Utara regency (Van Meter and Van horn, 1975:472). This is done because it can influence the success of the role of indigenous institutions in the implementation of the community empowerment policy of Oetulu village Musi district of Central Timor Regency, each policy implementing body/agency that in this case is the traditional institution of Oetulu village must feel it has its own duties based on the standards and policy objectives that have been set before.

e. Social, economic, and political conditions

Social, economic, and political conditions include environmental, economic resources that can support the successful role of indigenous institutions in the implementation of the community empowerment policy of Oetulu village Musi district of Timor Tengah Utara regency. The impact of economic, social, and political conditions on public policy has been the center of great attention over the past decade. Van Meter and Van Horn revealed: The extent to which the external environment supports the success of the established public policy, the external environment is economic, social, and political. Economic resource support can support the successful implementation of the community empowerment policy of Oetulu village Musi district, Timor Tengah Utara regency, and in the political environment, the support of the political elite is indispensable in supporting the successful role of indigenous institutions in the implementation of the policy of empowering the people of Oetulu village Musi district of Timor Tengah Utara regency (Van Meter and Van horn, 1975:471). Changes in economic, social and political conditions can affect the interpretation of the problem and thus will affect the way the program is implemented. Variations in the political situation affect the implementation of work. The government transition can result in changes in the way policies are implemented without changing the policy itself.

f. The disposition of implementers

The disposition of implementers in the implementation of the community empowerment policy of Oetulu village Musi district of Timor Tengah Utara regency refers to the opinion of Van Meter and Van Horn (1975:472) covering three important things, namely:

1) Implementer's response to the policy, which will affect his willingness to carry out his role as an indigenous institution in the implementation of Oetulu village community empowerment policy

2) Cognition, namely his understanding of policies related to the role of indigenous institutions in the implementation of community empowerment policy Oetulu District Musi Timor Tengah Utara regency

3) The intensity of the implementor's disposition is the preference of values owned by implementors in the context of the role of indigenous institutions in the implementation of the community empowerment policy of Oetulu village, Musi district, Timor Tengah Utara regency. 


\subsection{Empowerment}

Empowerment, a concept born as part of the natural development of western society and culture, especially in Europe, literally empowerment means "to give power or authority to act," which means to give power or transfer power and "to give the ability to or enable" which is interpreted as an attempt to give members ability or empowerment. In line with the above, prijono and pranaka (1996:44-45) state that The concept of empowerment may be seen as part or soulful with the traditions of the second half of the 20th century that today are widely known as the post-modernism tradition, with heavy points of attitudes and opinions whose orientation is the anti-structural system and anti determinism applied to the world of power. Paul, in the book restructuring and organizational empowerment (Sedarmayanti, 2000:78) states that empowerment means equitable sharing of power so as to increase political awareness and power of weak groups and increase their influence on the process and results of development.

Empowerment or empowerment is a strategy or paradigm of development implemented in community development activities, especially in developing countries. This empowerment arises because of the failures experienced in the process and implementation of development that tend to be centralistic such as community development or community development. This model does not provide a direct opportunity for the people to engage in a development process, especially in the decision-making process concerning the selection of officials, planning, implementation, and evaluation of development programs.

As mentioned above, the understanding of community empowerment actually refers to the word "empowerment," which attempts to actualize all the potential that the community has. Kartasasmita (1996:3) states that community empowerment is a concept of economic development that encapsulates social values so that in that frame of mind, efforts to empower people can be seen from three sides, namely:

1. Creating an atmosphere or climate that allows people's potential to develop (enabling). Here the turning point is the recognition that every human being, society has potential that can be developed. That is, no society is at all without power. Empowerment is an effort to build that power by encouraging, motivating, and raising awareness of its potential and striving to develop it.

2. Strengthening the potential or power possessed by the people (empowering). This strengthens the real measures and inventory of various inputs as well as the opening of access to various opportunities that will make the community more empowered. Therefore, there needs to be a special program for the less empowered because programs that apply to all cannot always touch this layer of society.

3. Empowering also means protecting. In the process of empowerment, it must be prevented that the weak become weaker because of the lack of power in the face of the powerful. Therefore, protection and daringness to the weak are fundamental in the concept of community empowerment. Protecting does not mean isolating or covering yourself from interactions. Protecting should be seen as an effort to prevent unbalanced competition and strong exploitation of the weak.

Wahyono et al. (2001:8) state that the approach of community empowerment emphasizes the importance of self-reliant communities as a system that organizes them. Such an empowerment approach is expected to give individuals roles not as objects but as perpetrators who determine their own lives. This approach of human-centered development (people-centered development) then undersized the insights of local resource management (community-based recourse development), a people-centered development planning mechanism that emphasizes social learning technology and program formulation strategies. Whatever the goal one wants is to improve people's abilities.

\subsection{Village}

Common sense is a widely used notion by the general public about the fact or about the definition of a particular object discussed. In general, the village is defined by the community as a place to live a group of residents characterized by the use of grammar with a strong local accent, relatively low level 
of education. Generally, the citizens have livelihoods in the field of agriculture or marine. The Indonesian General Dictionary mentioned villages are (1) areas inhabited by a number of families who have a system of self-government (headed by the Village Chief), (2) a group of houses outside the city that are the unity of kampongs, hamlets, (3) hick or hamlets (in the sense of inland areas or opponents of the city), (4) places, land, regions (Poerwadarminta, 2007:286).

Kartohadikoesoemo (1984:280) states that the village is a legal entity in which a powerful society resides, and the community holds its own government. While the definition of the village, according to Ndraha (1981:33) is the lowest unit of government organization, has a certain territorial boundary, directly under the sub-district, and is a unit of the legal community that has the right to organize its household.

Common characteristics of the village according to Suhartono (2000:14), namely:

1. Generally located or very close to the center of the agricultural area (agrarian)

2. In the region, agriculture is the dominant economic activity

3. Soil mastery factor determines the pattern of people's lives

4. Unlike in large towns or towns where most of the population is migrants, the villager population is more "replaced by its own"

5. Social control is more informal, and interaction between villagers is more personal in the form of face-to-face

6. It has a relatively high level of homogeneity and relatively tighter social ties than the city

Based on the above village understandings, the village has its own autonomy and territorial boundaries to regulate and take care of the villagers' interests. With the enacting of Law No. 6 of 2014 on Villages, the village is required to be independent in carrying out its government affairs, especially in the management of village finances. The source of village income derived from the village's original income is a form of village independence in managing finance. So the village is not dependent on the transfer of funds from the local government or the central government.

Law Number 6 of 2014 concerning Villages Article 18 explains that village authority includes authority in the field of village government, implementation of village development, village community development, and village community empowerment based on community initiatives, origin rights, and village customs. Furthermore, article 19 is explained, "Village Authority includes authority based on the right of origin; local authority on a village scale; authority assigned by the government, provincial government, or district/city local government." The exercise of authority is based on the rights of origin and local authority of the village scale as regulated and managed by the village. The implementation of the assigned authority and the implementation of other duty authorities of the government, provincial, local government, or district/city local government is taken care of by the village.

\subsection{Traditional institutions in the village}

Village Customary Institution or other designation in the general provisions of Ministry of Home Affairs Regulation 18 the year 2018 on Village Community Institutions and Village Customary Institutions is an institution that organizes customs functions and becomes part of the original arrangement of villages that grow and develop on the initiative of village people. As the Village Community Agency or other name or BPD mentioned in Ministry of Home Affairs Regulation 18 of 2018 on Village Community Institutions and Village Customary Institutions is an institution that performs the functions of government whose members are representatives of the villagers based on regional representation and democratically appointed.

In Ministry of Home Affairs Regulation 18 of 2018 on Village Community Institutions and Village Indigenous Institutions, Chapter III Article 9 on the Establishment of Village Customary Institutions stated that:

1. The Village Government and the villagers can establish Traditional Institutions in the Village.

2. Establishment of Traditional Institutions in the Village by meeting the requirements of: 
a. Based on Pancasila and The Constitution of the Republic of Indonesia year 1945

b. Actively develop local values and customs that are not contrary to human rights and adhered to by the community;

c. Based in the local village

d. Its existence is beneficial and needed by the villagers

e. Have a fixed management

f. Have a permanent secretariat

g. Not affiliated with political parties.

Whereas the duties and functions of Village Traditional Institutions in Ministry of Home Affairs Regulation 18 of 2018 concerning Village Community Organizations and Village Customary Institutions Article 10 are:

1. As a partner in empowering, preserving, and developing customs as a form of recognition of the customs of the Village community.

2. In carrying out the tasks referred to in paragraph (1), the Village Traditional Institution functions:

a. Protecting the cultural identity and traditional rights of indigenous peoples including birth, death, marriage and other elements of kinship.

b. Preserving ulayat rights, ulayat land, customary forest, and other customary assets and / or assets for the source of livelihoods of the community, preserving the environment, and overcoming poverty in the village.

c. Developing consensus deliberations for decision making in Village deliberations

d. Developing customary values in the settlement of disputes over inheritance, land and conflicts in human interactions.

e. Developing customary values for peace, tranquility and order of the Village community.

f. Developing customary values for health activities, community education, arts and culture, environment, and others

g. Developing cooperation with other Village Customary Institutions.

\section{Research methodology}

The research method used in this research was a descriptive research method with a qualitative approach. The informants of this study were determined purposively with a total of 36 people with the following details:

1. 1 head of Oetulu village

2. 1 person in charge of the Oetulu village customary institution

3. 4 people from the Oetulu village Community Organization

4. 30 people from Oetulu village Community

Researchers carried out the data collection stages according to Creswell (2016: 254-255) as qualitative observation, qualitative interview, tracing qualitative documents, and qualitative audio and visual material (qualitative audio and visual materials).

The explanation of each data analysis step proposed by Creswell (2016: 264-268) related to the terminology used by researchers is as follows:

1. Researchers begin to process and prepare data for analysis.

2. The second step is to read the data as a whole

3. The next step is to start coding all the data and group them into three categories, namely:

a. Codes related to the main topic that is widely known by readers in general, based on previous literature and common sense.

b. Shocking and unexpected codes at the start of the study.

c. Codes that are odd and have a conceptual appeal to the reader.

3. Next, apply a coding process to describe the settings (domains), people (participants), categories, and themes to be analyzed..

4. The next step is for the researcher to describe the above themes and present them again in a qualitative narrative/report.

5. The final step is interpreting qualitative research or interpreting the data. 


\section{Results and discussion}

To analyze how the role of traditional institutions in the implementation of community empowerment policies in Oetulu village, Musi district, Timor Tengah Utara regency, in the results of this study and discussion, the author uses the policy implementation model from Donald Van Meter and Carl E. Van Horn (1975) which states that there are six variables which influences policy implementation. Furthermore, the six policy implementation variables, according to Donald Van Meter and Carl E. Van Horn (1975) will be related to the phenomena in the research location and will be discussed in more depth as follows:

\subsection{Policy standards and objectives}

Policy standards and objectives are needed to direct the implementation of policies; this is done so that they are in accordance with the planned program. According to Van Meter and Van Horn (1975: 464), in determining standards and policy goals, researchers can use statements from policymakers such as regulations and program guidelines so that implementation can run in accordance with policy objectives and does not cause multiple interpretations between implementers.

The opinion of Van Meter and Van Horn if it is related to the role of traditional institutions in the implementation of community empowerment policies in Oetulu village, Musi district, Timor Tengah Utara regency, the policy standards are guided by the Decree of the Head of Oetulu village Number 7 / KEP / KDO / I / 2019 concerning the Formation of Traditional Institutions where One of the duties and functions of the customary institution is its role in empowering the community, while the target for the policy is all people who live in Oetulu village, Musi district, Timor Tengah Utara regency.

In its implementation, the policy standards related to customary institutions in Oetulu village Decree of the Head of Oetulu village Number 7 / KEP / KDO / I / 2019 concerning the Formation of Traditional Institutions were not formulated effectively by the Oetulu village government, which resulted in policy failure in its implementation (unsuccessful implementation). Hogwood and Gunn in Wahab (1997: 61) state that unsuccessful implementation occurs when a certain policy has been implemented according to plan, but considering that external conditions are not favorable, the policy is not successful in realizing the desired impact or outcome. This is usually influenced by factors:

1. Bad execution

2. The policy itself is bad (bad policy). Since the beginning, the policy has been bad, in the sense that it has been sloppily formulated, is not supported by adequate information, wrong reasons, or unrealistic assumptions and expectations.

3. The policy itself has bad luck (bad luck)

Based on the statements of Hogwood and Gunn in Wahab (1997: 61) and related to the results of research related to the role of the Oetulu village customary institution in empowering the community, it can be stated that the policy itself is bad (bad policy). Since the beginning, these policy standards have been poor, in the sense that they have been sloppily formulated, are not supported by adequate information, wrong reasons, or unrealistic assumptions and expectations. The author states that the policy standard is indeed bad because, in the formulation and implementation of this policy standard, the Oetulu village Customary Institution is not given the authority to regulate their own activities, besides that the Oetulu village community itself does not use the existence of the Oetulu village Traditional Institution if problems such as problems occur customary land, marriage issues or the determination of the boundaries of tribal land, the community prefers to consult with the tribal chief and open customary institutions. Another thing is that this policy standard never regulates the authority of the Oetulu village Traditional Institution for program design related to its activities in empowering the community, the authority of customary institutions such as circumcision so that the Oetulu village government is more prominent.

From the negative phenomena related to this policy standard, it has led to the policy target, namely the Oetulu village community, who should have been empowered by the Oetulu village Customary Institution, have not felt the existence of this Oetulu village customary institution even though if its 
history was traced, the Oetulu village customary institution existed before Oetulu village was founded which has been decreasing -decreased and until now it continues to carry out, maintain and maintain local customs even the existence of this institution has existed long before the existence of a standard policy in the form of a legal umbrella of Law Number 6 of 2014 concerning Villages and accompanying attributive regulations, namely the Regulation of the Minister of Home Affairs of the Republic of Indonesia 18/2018 concerning Village Social Institutions and Village Traditional Institutions and Oetulu village Head Decree Number 7 / KEP / KDO / I / 2019 concerning the Establishment of Traditional Institutions stipulated and implemented.

\subsection{Resources}

In implementing the community empowerment policy, the customary institution in Oetulu village, Musi district, and Timor Tengah Utara regency needs to be supported by resources, both human and non-human resources. These policy sources are indispensable for the success of a policy made by the government. According to Widodo (2011: 98), the resources mentioned include human resources, financial resources, and equipment resources (buildings, equipment, land, and other spare parts) needed to implement the policy.

The human resource of the Oetulu village customary institution was determined to be 8 people by the Head of Oetulu village with the Decree of the Oetulu village Head Number 7 / KEP / KDO / I / 2019 concerning the Establishment of a Traditional Institution dated January 30, 2019, consisting of 1 chairman and 7 members. However, the adequacy of the number of resources in implementing a policy is not as fast as then it can guarantee the success of the policy if the policy implementers are unable to make the best use of the resources. It is known that the human resources of the Oetulu village customary institution in their role to empower the community are not utilized by the Oetulu village Government, the Oetulu village customary institution does not have a function in health, education, social and economic affairs as well as community empowerment, Oetulu village customary institutions also do not have A program/activity design is in accordance with the prevailing customs in the village, the implementation of the Oetulu village Government activities also tends not to involve social institutions but prioritizes community participation. For financial resources, the Oetulu village customary institution only gets incentives from the allocation of village funds each year to pay 8 administrators of the Oetulu village customary institution.

The success of policy implementation is highly dependent on the ability to utilize available policy resources to facilitate implementation activities. Financial resources are an important calculation in the success of policy implementation. Lack of or limited funds or incentives in policy implementation is a major contribution to the failure of policy implementation (Van Meter and Van Horn, 1974: 465). Agreeing with Van Meter and Van Horn, Goggin et al. (1990: 31) stated that one of the criteria for measuring the success of policy implementation is the number of funds allocated, assuming that the greater the number of funds allocated, the more seriously the policy is implemented. However, in Oetulu village, the inadequacy of the financial resources of the village customary institutions also hampers its role in implementing the community empowerment policy, this is due to the absence of a special budget allocation from the local government or from the Oetulu village itself for the operationalization of customary village institutions so that it also hinders the role of traditional village institutions in implementing community empowerment policies in Oetulu village.

Another resource is facilities. Facilities, according to Edward III in Widodo (2010: 96) are an important factor in policy implementation. Implementers may have sufficient staff, understand what to do, and have the authority to carry out their duties, but without supporting facilities (advice and infrastructure), the implementation of the policy will not be successful. However, until now the Oetulu village customary institution does not have the facility resources in the form of a permanent building to facilitate all activities of the customary village institution.

\subsection{Communication between organizations and strengthening activities}

Coordination is a powerful mechanism in the process of implementing public policies. The better the coordination of communication between the parties involved in a policy implementation process, the 
assumption is that errors will be very small to occur and vice versa. Communication will determine the success of achieving the goals of the implementation of public policies. Effective implementation occurs when decision-makers already know what they are going to do. Communication (or transmission of information) is needed so that decision-makers and implementers will be more consistent in implementing any policies that will be applied in society.

Referring to the opinion of Van Meter and Van Horn (1975: 466) and related to the role of customary village institutions in implementing community empowerment policies in Oetulu village, communication between organizations can be seen from; (1) There is coordination with other agencies, namely ties between the implementing agency and the implementing agency in the delivery of policies on community empowerment. In fact, the coordination between the Oetulu village Government and the Oetulu village customary institutions is still not effective wherein the implementation of Oetulu village government activities, the Oetulu village customary institutions tend to be excluded but prioritize community participation, which means that communication between organizations, namely the village government and Oetulu village customary community organizations is running. not optimal. Empowerment is all activities in the framework of maintaining, maintaining and developing customs and customary institutions that need to be preserved continuously. The village government of Oetulu seems to have not given a role to traditional institutions in empowerment activities.

The phenomenon of not optimal communication between organizations and strengthening activities in Oetulu village is inversely proportional to the opinion of Van Meter and Van Horn (1975: 466), who state that knowledge of what they will do can run if communication goes well so that every policy and regulatory decision implementation should be transmitted (or communicated) to the appropriate personnel department.

Communication between organizations in policy implementation, according to Quade (1984: 310) will be ideal if there is interaction and reaction from implementing organizations, target groups and environmental factors that cause pressure to emerge and are followed by bargaining or transactions. From this transaction, feedback was obtained which policymakers could use as input in the formulation of subsequent policies but in its implementation in Oetulu village, all types of communication between organizations in the form of interactions and reactions of the Oetulu village Traditional Institution were never accommodated and accommodated at the Oetulu village Government level so that There is no feedback that can be used as a recommendation in the formulation of further policies so that the implementation performance of the Oetulu village Customary Institution policy becomes lame, this happens because the Oetulu village Customary Institution has not received the trust of the village government and the community, the Village Government prefers to solve problems in their own way while the community do not take advantage of the existence of the Krena Village Customary Institution already has a tribal chief who is more trusted to take care of customary issues in the context of community empowerment.

In line with the statements of Van Meter and Van Horn (1975: 466) and Quade (1984: 310), Edward III (1984: 9-10) states that communication of a program can only be carried out properly if it is clear to the implementers. This customary institution should run in accordance with the duties and functions of the customary institutions that have been regulated. This customary institution was not automatically formed to complement the village administration where customary institutions support government activities in the village. When customary institutions can become good partners for the village government in carrying out their duties and functions, then the existing government in Oetulu village will run well. All the people of Oetulu village will feel the impact.

\subsection{Implementing agent characteristics}

The extent to which the interest groups in this study are the Oetulu village customary institutions implementing the community empowerment policy in Oetulu village, Musi district, Timor Tengah Utara regency, and supporting policy implementation. This includes the characteristics of the participants, namely supporting or rejecting, then also how the nature of public opinion in the 
environment and whether the political elite supports policy implementation. The characteristics of the implementing agency include the structure of the bureaucracy, norms, and patterns of relationships that occur in the bureaucracy that implements community empowerment policies in Oetulu village, Musi district, Timor Tengah Utara regency (Van Meter and Van Horn, 1975: 472). The attitude of the implementers in carrying out their duties and responsibilities as implementers of community empowerment policies in Oetulu village, Musi district, Timor Tengah Utara regency. This is done because it can affect the success of the role of traditional institutions in the implementation of community empowerment policies in Oetulu village, Musi district, Central Timor Regency, every agency implementing policies which in this case is the Oetulu village customary institution must feel that it belongs to their respective duties based on standards and policy objectives that have been set previously.

Each policy-implementing agency has its own characteristics, so Van Metter and Van Horn (1975: 471) present several elements that may affect the characteristics of implementing agents in an organization to implement policies. From Van Metter and Van Horn's statement and related to research problems regarding the role of customary village institutions in implementing community empowerment policies in Oetulu village, the research findings are as follows; (1) the competence and size of the staff of the Oetulu village customary institution in the results of interviews and observations by the author, it is known that the management of the Oetulu village customary institution is chosen based on competence, namely the understanding of each customary institution management regarding the cultural values and customs that apply in Oetulu village, but in its implementation, competence the management of the Oetulu village customary institution is not optimally utilized by the Oetulu village Government. Village customary institutions are not always involved in decision making in Oetulu village, especially regarding customary decisions so that the role of the Oetulu village customary institution as a forum for community empowerment is not optimal, (2) the level of hierarchical supervision of sub-unit decisions and processes in the policy implementing agency is based on observations and interviews In-depth, the authors note that the customary village institutions in each of their decision-making roles are supervised by the village head as the head of the Oetulu village government and also supervised by the Oetulu village community. This is according to Ripley and Franklin (1986: 11) regarding the level of compliance of individual subordinate agents to the superior's individual agents (3) the political sources of an organization as stated by Grindle (1980: 10) that the political process can be seen through decision making involving actors. Politics but in its implementation, the implementer of community empowerment policies, namely the customary institutions of Oetulu village, is not sourced or affiliated with any political source, (4) open level of communication, which is defined as a network of free horizontal and vertical communication among policy implementers as well as the level of freedom that is relatively high in communication with individuals outside the organization. This is in line with the statement from Ripley and Franklin (1986: 11) that the implementation process requires implementers to be more flexible in implementing adjustments.

In its implementation in Oetulu village, the customary village institution in its role as an institution that helps the village government empower the community has an open level of communication both vertically and horizontally, but this communication is constrained at the vertical level where all input provided by the customary village institution is related to the empowerment of the Oetulu village community not accommodated at the Oetulu village Government level. This is inversely proportional to the regulations stated that customary village institutions are partners for the village government in empowering village communities.

\subsection{Social, economic, and political conditions}

According to Van Metter and Van Horn (1975: 471), the social, economic, and political conditions are the extent to which the external environment contributes to the success of established Public policies. An unfavorable economic, social and political environment can be the culprit for the failure of the performance of policy implementation. Therefore, efforts to implement policies must also pay attention to the conducive conditions of the external environment. Van Metter and Van Horn also hypothesized that the economic, social, and political environment of the jurisdiction or implementing 
organization would influence the character of the executing agency, the propensities of the implementers, and the achievements themselves. Environmental conditions can have an important influence on the willingness and ability of jurisdiction or organization to support the structures, vitality, and expertise that exists within the administrative body as well as the level of political support it has. Environmental conditions may cause the implementers of a policy without changing their personal choices about the policy. Finally, these environmental factors are seen to have a direct influence on the delivery of public services. Environmental conditions may magnify or limit achievement, although the inclination of implementers and other forces in this model also has an influence on implementation.

Quoting research questions from Van Meter and Van Horn regarding the economic, social, and political environment that affect jurisdictions or organizations where the Oetulu village customary institution carries out the implementation of community empowerment policies, the research findings can be stated as follows; (1) economic resources within the jurisdiction or implementing organization are not sufficient to support the implementation of community empowerment policies to succeed where the Oetulu village customary institution does not receive a specific budget allocation to support all activities of the customary village institution, (2) prevailing economic and social conditions cannot be influenced by the customary village institution because the Oetulu village customary institution does not have a clear design program of activities. This causes the economic and social conditions of the community not to be affected by the existence of customary institutions, (3) the majority of the community states that due to the absence of an activity program design, the nature of public opinion on the role of the Oetulu village customary institution in community empowerment policies has not shown any real performance, (4) The elites in Oetulu village stated in the results of the interviews that they support the role of traditional institutions in implementing community empowerment policies, but in its implementation, customary institutions are not involved in any policy formulation and policy decision making in Oetulu village.

The dimensions of the social, economic, and political environment are external environments that contribute to the failure or success of policies because assessing the performance of policy implementation is the extent to which the external environment supports the policies. The unfavorable social, economic, and political environment can be a source of problems for policy implementation performance. Therefore, policy implementation implies external environmental conditions that support policy implementation.

In its implementation in Oetulu village, the external dimension of the social and political economy environment in supporting the role of Village Traditional Institutions in implementing community empowerment policies is known that internal economic resources are not sufficient to support policy implementation. In addition, the prevailing economic and social conditions, namely the community's economic conditions and the community's social conditions, have not been influenced by the customary village institutions because the Oetulu village customary institution does not have a clear design program of activities. The majority of the community stated that as a result of the absence of an activity program design, the nature of public opinion on the role of the Oetulu village customary institution in the community empowerment policy had not shown any real performance. In Oetulu village, the elites in Oetulu village support the role of customary institutions in implementing community empowerment policies. However, in its implementation, customary institutions are not involved in every policy formulation and policy decision making in Oetulu village. This happened because of the sectoral ego of the Oetulu village Government, who considered the existence of the Oetulu village Customary Institution only as a complement to the village customary institution and also as an implementation of the village law but not as a village partner in empowering the community.

This phenomenon that occurs in Oetulu village is in line with the opinion of Van Metter and Van Horn (1975: 471), which states that the economic, social and political environment is not conducive as happened in Oetulu village regarding the role of the Oetulu village Customary Institution in implementing community empowerment policies. Be the culprit for the failure of the performance of 
policy implementation. Therefore, efforts to implement policies must also pay attention to the conducive conditions of the external environment. Strengthening the statement from Van Meter and Van Horn, Korten (1988) in Tarigan (2000: 19) argues that a program will be successful if it meets the criteria for conformity between the program and the beneficiary, but what happened in Oetulu village, a program that includes the economic condition of the Customary Institution. Inadequate Oetulu village causes a mismatch between the program and its beneficiaries, in this case the Oetulu village community who should be empowered by the Oetulu village Customary Institution, another thing according to Korten (1988) in Tarigan (2000: 19) is the program's suitability with the implementing organization where the What happens in Oetulu village is an external environment in the form of political interests of the Oetulu village Government which overrides the role of village customary institutions as village partners in empowering the community which also hinders the implementing organization which in this case is the Oetulu village Customary Institution so that it sacrifices the interests of the social environment which in this case is the community Oetulu village, hereinafter is the suitability between the user group or the social environment, in this case the Oetulu village community and the implementing organization, in this case the Oetulu village Customary Institution. In its implementation, the political environment has hindered the implementing organization, especially in providing economic resources, resulting in the inactivity of the Oetulu village Customary Institution, which results in the lack of empowerment of the social environment, in this case, the people of Oetulu village.

\subsection{Implementer disposition}

In the opinion of Van Metter and Van Horn, the disposition of the implementor or the attitude of acceptance and rejection of the policy implementing agency greatly affects the success or failure of public policy implementation. Their attitude can be influenced by their view of a policy and how they see the influence of that policy on their organizational interests and personal interests.

Van Mater and Van Horn (1975: 472) explain that the disposition in policy implementation begins with filtering (be filtered) first through the perceptions of the implementers (implementers) in which limits the policy is implemented. There are three kinds of response elements that can affect their ability and willingness to implement a policy, including first, the direction of their response, whether they accept, be neutral or reject (acceptance, neutrality, and rejection). Second, knowledge (cognition), understanding and deepening. (Comprehension and understanding) of policies, and third intensity of policies. Understanding the general intent of a standard and policy objectives is important. Because, after all, successful policy implementation can fail (frustration) when of ficials are not fully aware of policy standards and objectives. The direction of the disposition of the implementers (implementers) to standards and policy objectives is also "crucial."

Implementers may fail in implementing the policy because they reject the goal of a policy (Van Meter and Van Horn, 1975: 473). On the other hand, the widespread and profound acceptance of policy standards and objectives among those responsible for implementing these policies is a great potential for the successful implementation of policies (Kaufman in Van Meter and Van Horn, 1975: $\underline{473)}$.

The intensity of the disposition of the implementers can affect the implementer (performance) of the policy. Lack or limited intensity of this disposition will lead to failure of policy implementation. For the role of customary village institutions in the implementation of community empowerment policies in Oetulu village, it was found that facts about the disposition of the implementers or the attitude of acceptance and rejection of the policy implementing agencies were; (1) the response of the implementer, namely the management of the Oetulu village customary institution towards policies that will affect their willingness to implement policies. Edward III in Winarno (2005: 142) states that if the implementers have a positive tendency or attitude or support for policy implementation, there is a high probability that policy implementation will be carried out in accordance with the initial decision. On the other hand, if the implementers have a negative attitude or refuse to implement the policy because of a conflict of interest, the implementation of the policy will face serious obstacles. In its implementation, the Oetulu village Traditional Institution, as an institution that plays the role of 
empowering the community in Oetulu village, is always ready to support the village government as a partner in empowering the community. However, the implementation of Oetulu village Government activities also tends not to involve traditional village institutions but prioritizes community participation such as dispute resolution customary land between residents, solving problems of premarital relations where the community prefers to present traditional elders rather than traditional institutions. The role of customary institutions is increasingly invisible due to the phenomenon that the Oetulu village Government does not seem to give a role to traditional institutions in strengthening the order of the customary values, which as a result is that the traditional values are slowly disguised because their potential is not being utilized in Oetulu village. This contradicts the statement of Robert Eyestone in Winarno (2007: 15), which defines public policy as "good relations between government units and their environment," but in its implementation, the relationship between the Oetulu village Government and the Oetulu village Traditional Institution is not going well, (2) cognition, namely the understanding of the management of the Oetulu village customary institution of its role in empowering. Quoting Wildasky's opinion in Leslie A. Pal (1987: 9) that cognitive activity, namely activities related to learning and thinking, means that policy problems are defined, defined, solved, and reviewed. The cognitive element has a central role in this process, although it is not dominant. It is said to have a central role, because according to Leslie A. Pal (1987: 19) that the real policy process is only a process of discussing and debating their ideas about priorities, problems, and solutions. The cognitive aspect is thinking about the position of a person or policy implementer, in this case, the management of the Oetulu village Customary Institution regarding their role as an institution that empowers the people of Oetulu village, as long as they are needed in clarifying or justifying and rationalizing their views or opinions. In its implementation, the cognitive aspects of the policy implementers, namely the Oetulu village Customary Institution, cannot be said to be good because the policy implementers do not understand the policies governing the duties and functions of traditional institutions in the village. This is related to learning and thinking, meaning that policy issues are defined, defined, resolved, and reviewed by policy implementers. In this case, the management of the Oetulu village Customary Institution does not carry out their duties and functions as partners in empowering the people of Oetulu village. This happens because the Oetulu village customary institution does not have a program/activity design according to the prevailing customs in the village, (3) the intensity of the implementer disposition of the Oetulu village customary institution management, namely the value preference that the implementer of the community empowerment policy. In its implementation, the Oetulu village customary institution chooses to uphold the customs of an ancestral culture that have been preserved from generation to generation and combined with religion and village government if something is not suitable, the customary institution will find a middle way so as not to harm anyone, both traditional institutions, society and government Oetulu village itself, but this is only an unwritten custom because the Oetulu village customary institution does not have a written program/activity design according to the customs that apply in the village.

\section{Conclusion}

The role of customary institutions in the implementation of community empowerment policies in Oetulu village, Musi district, Timor Tengah Utara regency was analyzed using the policy implementation model from Donald Van Meter and Carl E. Van Horn (1975), which states that six variables influence implementation, namely; (1) The policy standard in the form of rules regarding customary institutions in Oetulu village has been flawed at the policy formulation stage where it is not regulated regarding the role of the Oetulu village Traditional Institution as a partner of the village government in empowering the community so that it can be stated that these policy standards tend to be bad policies or policies that are already in place. bad from the start so that the Oetulu village government has not been used effectively, as a result of which the policy targets, namely the empowered Oetulu village community, have not felt the existence of the Oetulu village customary institution and because there are no good policy standards, the people of Oetulu village prefer to return to deliberation with the tribal chief compared to utilizing the existence of the Oetulu village Customary Institution, (2) the human resources of the Oetulu village customary institution are not utilized by the Oetulu village Government and only as a flawed village institution without duties and functions, the financial resources of the Oetulu village customary institution are only There is an incentive from the allocation of village funds each year to pay 8 administrators and there is no budget 
allocation for community empowerment activities as mandated by law, while for facility resources, until now the Oetulu village customary institution does not have a permanent building to expedite everything activities of village customary institutions, (3) Communication between organizations and strengthening activities is still ineffective where Oetulu village customary institutions tend not to be involved in decision making at the community level and at the village level, which means that communication between organizations in Oetulu village is not optimal, (4) The characteristics of the implementing agency have an open level of communication both vertically and horizontally but this communication is constrained at the vertical level where all input provided by the village customary institutions related to community empowerment in Oetulu village is not accommodated at the community level or the Oetulu village Government, (5) the economic conditions in The jurisdiction or implementing organization is not sufficient to support the implementation of community empowerment policies, the prevailing social conditions have not been influenced by village customary institutions, the elites in Oetulu village stated that supporting the role of customary institutions in implementing community empowerment policies but in implementing customary institutions were not involved in every policy formulation and policy decision making in Oetulu village, (6) the disposition of the implementer where the response of the management of the Oetulu village customary institution to the policy is always ready to support the village government as a partner in empowerment the community but in its implementation it does not involve village customary institutions, cognition in its implementation, Oetulu village traditional institutions do not carry out their duties and functions as partners in empowering the people of Oetulu village, the intensity of the implementer disposition of the management of the Oetulu village customary institution in its implementation chooses to uphold the customs of the ancestral culture It has been preserved from generation to generation and combined with religion and village government if something is not suitable then the customary institutions will find a middle way so as not to harm anyone, both the traditional institutions, the community and the Oetulu village government itself, but this is only an unwritten habit because of Village customary institutions Oetulu does not have a written program / activity design according to the customs that apply in the village.

The inhibiting factors for the implementation of the role of traditional institutions in the implementation of community empowerment policies in Oetulu village, Musi district, Timor Tengah Utara regency are; (1) no use of customary village institutions as village partners in empowering the community, (2) There is no program/activity design to carry out their duties and functions as village partners in empowering the community, (3) lack of resources, namely lack of professionalism in human resources of customary institutions Oetulu village, lack of implementation instructions and technical instructions regarding procedures for implementing the policies of the Oetulu Vvllage customary institution, budget limitations, and facilities.

\section{References}

Abdulyani. (2012). Sosiologi: Skematika, Teori, dan Terapan. Jakarta. PT. Bumi. Aksara

Andriarsi, Melati Kristina. (2020). Sebaran Masyarakat Adat di 31 Provinsi di Indonesia. https://katadata.co.id/padjar/infografik/5f8030631f92a/sebaran-masyarakat-adat . Diakses pada 1 Desember 2020 pukul 8.36 WITA.

Aritonang, A. I. (2011). Kebijakan Komunikasi di Indonesia: Gambaran Implementasi UU No. 14 tahun 2008 tentang Keterbukaan Informasi Publik. Jurnal ASPIKOM, 1(3), 261-278.

Creswell, Jhon W. 2016. Research Design Pendekatan Kualitatif, Kuantitatif, dan Mixed. Yogyakarta: Pustaka Pelajar.

Edward III, George C. (1980). Implementing Public Policy. Washington DC: Congressional Quarterly Press

Goggin, Malcolm L et al. (1990). Implementation, Theory and Practice: Toward a. Third Generation, Scott, Foresmann and Company, USA.

Grindle, Merilee S. (1980). Politics and Policy Implementation in The Third World. New Jersey: Princeton University Press

Kartasasmita Ginanjar. (1997). Pemberdayaan Masyarakat: Konsep Pemnagunan yang Berakar Pada Masyarakat. Yogyakarta. Universitas Gajah Mada. 
Leslie Pal. A. (1997). Public Policy Analysis, An Introduction, 2nd edn. Scarborough, Ontario. Nelson Canada

Kartohadikoesoemo Soetarjo, (1984). Desa. Jakarta. PN Balai

Ndraha, Taliziduhu. (1981). Budaya Organisasi, Jakarta. PT. Rineka Cipta

Nugroho Riant. (2006). Kebijakan Publik Untuk Negara-negara. Berkembang; Model-model Perumusan, Implementasi, dan Evaluasi. Jakarta. Elex Media Komputindo

Pemerintah Desa Oetulu. (2019). Keputusan Kepala Desa Oetulu Nomor 7 / KEP / KDO / I / 2019 tentang Pembentukan Lembaga Adat. Sekertariat Desa Oetulu.

Pemerintah Indonesia. (2018). Permendagri 18 tahun 2018 tentang Lembaga Kemasyarakatan Desa dan Lembaga Adat Desa. Berita Negara Republik Indonesia No. 569. Sekertariat Negara. Jakarta.

Pemerintah Indonesia. (2014). Undang-Undang Republik Indonesia No. 6 Tahun 2014 tentang Desa. Lembaran Negara Republik Indonesia. No.7. Sekretariat Negara.Jakarta.

Prijono, Onny. Pranarka. (1996). Pemberdayaan Konsep, Kebijakan, dan. Implementasi. Jakarta. Centre For Strategic And International

Poerwadarminta. (2007). Kamus Umum Bahasa Indonesia. Jakarta. PN Balai.

Quade. (1984). Analsysis For Public Decisions. New York. Elseiver Science Publisher

Ripley, Randall B and Grace A. Franklin. (1986). Policy Implementation and Bureaucracy. Second Edition. Chicago: The Dorsey Press

Sedarmayanti. (2000). Good Governance ( Kepemimpinan yang Baik ) Jilid II. Bandung. Mandar Maju.

Soenarko. (2003). Public Policy: Pengertian Pokok Untuk Memahami dan Analisa Kebijaksanaan Pemerintah. Cetakan Kedua. Surabaya. Airlangga University Press.

Soerjono Soekanto. (2006). Sosiologi Suatu Pengantar. Jakarta. Raja Grapindo Persada

Strzelecka, M., Boley, B. B., \& Woosnam, K. M. (2017). Place attachment and empowerment: Do residents need to be attached to be empowered?. Annals of Tourism Research, 66, 61-73.

Suhartono. (2000). Politik Lokal Parlemen Desa. Yogyakarta: Lapera Pustaka Utama.

Surjono, A., \& Nugroho, T. (2008). Paradigma, Model, Pendekatan dan. Pemberdayaan Masyarakat di Era Otonomi Daerah. Malang: Bayumedia Publishing.

Tarigan, Antonius. (2000). Artikulasi Konsep Implementasi Kebijakan: Perspektif, Model dan Kriteria Pengukurannya. Jurnal

Van Meter, D. S., \& Van Horn, C. E. (1975). The policy implementation process: A conceptual framework. Administration \& Society, 6(4), 445-488.

Wahab Abdul, Solichin. (2005). Analisis Kebijaksanaan: dari Formulasi ke Implementasi. Kebijaksanaan Negara. Jakarta. Sinar Grafika

Wahyono, Ary dkk, (2001). Pemberdayaan Masyarakat Nelayan. Yogyakarta. Media Pressindo.

Widodo, Joko. (2011). Analisis Kebijakan Publik. Jakarta. Bayumedia

Winarno, Budi. (2005). Teori dan Proses Kebijakan Publik. Yogyakarta. Media Pressindo. 